\title{
AKTUALNA PRAVNA PITANJA OBVEZE ZRAČNIH PRIJEVOZNIKA NA PRIKUPLJANJE I PRIJENOS PODATAKA O PUTNICIMA U SMISLU NAJNOVIJIH RJEŠENJA EUROPSKE (HRVATSKE) PRAVNE STEČEVINE
}

Izv. prof. dr. sc. Željka Primorac*

UDK: 347.824.2:342.738(4)EU

347.518:347.824.2(4)EU

$342.738:: 341.176(4) \mathrm{EU}$

DOI: 10.3935/zpfz.69.56.07

Izvorni znanstveni rad

Primljeno: studeni 2019.

Tematsku koncepciju rada čine pravna pitanja uloge i važnosti obveze zračnih prijevoznika na prikupljanje i prijenos podataka o putnicima (i o samom prijevozu) koji služe putnikovoj identifikaciji, a glede unaprjeđenja kontrole ulaska u EU. Predmetno istraživanje ujedno ima cilj izvršiti pravnu analizu pojedinih aspekata obveze zračnih prijevoznika u pogledu sustavnog prikupljanja i prenošenja brojnih osobnih podataka o putnicima radi sprečavanja, otkrivanja, istrage i kaznenog progona kaznenih djela terorizma i teških kaznenih djela. Analizirajući svrhu, doseg, kriterije i problematiku primjene postojećih pravnih rješenja na europskoj razini (Direktive 2004/82/EZ i Direktive (EU) 2016/681), autorica posebnu pozornost posvećuje razmatranju modaliteta implementacije rješenja europske pravne stečevine u hrvatski pravni poredak (Zakon o nadzoru državne granice iz 2013. godine i Zakon o prijenosu i obradi podataka o putnicima u zračnom prometu u svrhu sprječavanja, otkrivanja, istraživanja i vođenja kaznenog postupka za kaznena djela terorizma i druga teška kaznena djela iz 2018. godine). Jasno ističući bitne sadržajne razlike unutar europskih i nacionalnih pravnih rješenja, autorica naglašava važnost otvorenih pitanja necjelovito uređene obveze zračnog prijevoznika na prenošenje API podataka o putnicima iz PNR evidencije u hrvatskom pravnom sustavu. Iznoseći prijedloge de lege ferenda autorica zagovara unificiranost u tumačenju, prenošenju i primjeni europske pravne stečevine.

Ključne riječi: prikupljanje i prijenos API podataka o putnicima, obveze zračnih prijevoznika, europska (hrvatska) pravna stečevina

Dr. sc. Željka Primorac, izvanredna profesorica Pravnog fakulteta Sveučilišta u Splitu, Domovinskog rata 8, Split; zeljka.primorac@pravst.hr;

ORCID ID: orcid.org/0000-0002-9880-0369 


\section{UVOD}

Zračni prijevoz jedan je od najsigurnijih oblika prijevoza. U 2018. europski zračni promet porastao je 3,8 \% u odnosu na 2017., ostvarivši više od 11 milijuna letova (prosječno 30.168 letova dnevno). ${ }^{1}$ Procjenjuje se da će se 2035. u Europi zabilježiti 14,4 milijuna letova, 50 \% više nego 2012., a prvi je cilj da se unatoč sve većem prometu zadrže postojeći visoki standardi sigurnosti. ${ }^{2}$ Međunarodna putovanja često mogu uključivati nezakonito useljavanje i pojedine terorističke aktivnosti, pa su njihovo sprječavanje i suzbijanje ciljevi kojima se teži na međunarodnoj i europskoj razini. Cilj Strategije Europske unije za borbu protiv terorizma ${ }^{3}$ jest globalna borba protiv terorizma i stvaranje sigurnije Europe $^{4}$, a neki od njezinih prioriteta su smanjenje izloženosti terorističkim napadima kroz zaštitu vanjskih granica te implementiranje općeprihvaćenih zajedničkih standarda o sigurnosti zračnog prometa. Počevši s napadima 11. rujna 2001. u SAD- $\mathrm{u}^{5}$, napadi na zračni promet postajali su sve inovativniji: bombaš s bombom u cipeli (2001.), pokušaji s eksplozivima u tekućem stanju (2006.), pokušaj stvaranja pukotine u zrakoplovu pomoću eksploziva skrivenoga u donjem rublju (2009.) i presretanje dviju bombi iz kućne radinosti koje su se

1 Eurocontrol, 2018's air traffic in a nutshell, https://www.eurocontrol.int/ news/2018s-air-traffic-nutshell (10. siječnja 2019.).

2 Strategija zrakoplovstva za Europu, COM(2015) 598 final, 7. prosinca 2015., pod 2.3., https://eur-lex.europa.eu/legal-content/HR/TXT/HTML/?uri=CELEX:52015DC0598\& from $=\mathrm{EN}$ (10. siječnja 2019.).

3 Vijeće Europe, Strategija Europske unije za borbu protiv terorizma, http://register.consilium.europa.eu/doc/srv?l=EN\&f=ST\%2014469\%202005\%20REV\%204 (12. ožujka 2019.).

4 Više o europskom pristupu borbi protiv terorizma vidi u: Konvencija Vijeća Europe o sprječavanju terorizma, Službeni list Europske unije, L 159, 22. lipnja 2018., str. 3 - 14; Horjan, A. M.; Šuperina, M., Izgradnja strategije unutarnje sigurnosti Europske unije: U pet koraka prema sigurnijoj Europi, Policijska sigurnost, vol. 21, br. 1, 2012., str. 87.

5 Detaljnije o ranjivosti zračnog prometa na koju su upozorili teroristički napadi na World Trade Center u New Yorku vidi u: Lee, A. J.; Nikolaev, A. G.; Jacobson, S. H., Protecting air transportation: a survey of operations research application to aviation security, Journal of Transportation Security, vol. 1, br. 3, 2008., str. 160 - 162. Više o posljedicama terorističkog napada na World Trade Center u New Yorku 2001. te o donošenju mnogobrojnih međunarodnih sigurnosnih standarda zaštite zračnog prometa vidi u: Weber, L., Aviation Security, u: Giemulla, E.; Weber, L. (ur.), International and EU Aviation Law, Kluwer Law International, 2011., str. 297 - 302. 
prevozile kao teretne pošiljke (2010.). ${ }^{6}$ S obzirom na učestale prijetnje sigurnosti zračnog prijevoza u EU-u, posljednji teroristički napad 2016. u međunarodnoj zračnoj luci Zaventem (u prostoru za check-in putnika) ${ }^{7}$ u Bruxellesu upozorio je na nužnost stalnog osnaživanja i usavršavanja europskih sigurnosnih standarda zaštite zračnog prometa. ${ }^{8}$ Poduzimanje navedenih mjera neupitno predstavlja i povećanje financijskih troškova za zračne luke. Naime, još je 2009. uočeno kako su troškovi sigurnosne zaštite dosegli do 35 \% ukupnih operativnih troškova zračnih luka, dok su prije rujna 2001. iznosili između 5 i $8 \% .{ }^{9}$ No, usklađivanje s višim standardima sigurnosne zaštite znači i snošenje većih troškova za zračne prijevoznike. ${ }^{10}$ Podaci o putnicima u zračnom prijevozu važan su alat globalnog pristupa borbi protiv terorizma, ali i instrument čija primjena ima znatan učinak na sprječavanje nezakonitog useljavanja i poboljšanje graničnih kontrola. Predmet istraživanja ovog rada odnosi se na analizu pravnih aspekata obveze zračnih prijevoznika na prikupljanje i prijenos podataka o putnicima koji su im dostupni prilikom rezervacije karata putnika ili prijave putnika na let (a služe identifikaciji tih osoba), ali i brojnih drugih osobnih podataka o putnicima koje putnici sami prijavljuju (zdravstveno stanje, način plaćanja, program vjernosti, podaci o prtljazi i dr.), upućujući na europska pravna ishodišta i opseg implementacije u hrvatski pravni sustav.

\section{OBVEZA ZRAČNIH PRIJEVOZNIKA NA DOSTAVLJANJE PODATAKA O PUTNICIMA PREMA RJEŠENJIMA DIREKTIVE 2004/82/EZ}

U cilju sprječavanja nezakonitog useljavanja i poboljšanja granične kontrole 29. travnja 2004. Vijeće Europske unije donijelo je Direktivu 2004/82/EZ o

6 Europska komisija, Politike Europske unije: Promet, 2014., str. 12, https://europa.eu/ european-union/topics/transport_hr (11. travnja 2019.).

7 Više vidi u: Martin, G.; Prager, F., Terrorism: An International Perspective, SAGE Publications Ltd, 2019., str. 640.

8 Više o terorističkim napadima u zračnom prometu u razdoblju 1931. - 2016. vidi u: Duchesneau, J.; Langlois, M., Airport attacks: The critical role airports can play in combatting terrorism, Journal of Airport Management, vol. 11, br. 4, 2017., str. 344.

9 Report from the Commission on financing aviation security, COM/2009/0030 final, 2. veljače 2009., str. 2, https://eur-lex.europa.eu/legal-content/HR/TXT/?uri=CELEX:52009DC (10. siječnja 2019.).

10 Više vidi u: Savić, I., Zračni promet, u: Radionov, N.; Marin, J. (ur.), Europsko prometno pravo, Pravni fakultet Sveučilišta u Zagrebu, Zagreb, 2011., str. 446. 
obvezi prijevoznika na dostavljanje podataka o putnicima. ${ }^{11}$ Prema odredbi čl. 3. st. 1. Direktive 2004/82/EZ na zahtjev tijela odgovornih za kontrolu osoba na vanjskim granicama prijevoznici ${ }^{12}$ su dužni (nakon završetka postupka prijave putnika $^{13}$ na let ${ }^{14}$, a prije izvršavanja samog prijevoza ${ }^{15}$ ) prenijeti podatke o putnicima koje će prevoziti - službenom graničnom prijelazu preko kojeg će te osobe ući na državno područje države članice. Direktiva 2004/82/EZ obvezuje zračne prijevoznike, koji izvršavaju prijevoz putnika na državno područje država članica, dostaviti osobne podatke o putnicima ${ }^{16}$ kojima raspolažu ${ }^{17}$, a služe samo

11 Direktiva 2004/82/EZ o obvezi prijevoznika na dostavljanje podataka o putnicima, Službeni list Europske unije, L 261, 6. kolovoza 2004., str. 24 - 27, na snazi od 5. rujna 2004., dalje u tekstu: Direktiva 2004/82/EZ.

12 Direktiva definira prijevoznika kao bilo koju fizičku ili pravnu osobu čija se djelatnost sastoji u prijevozu putnika zračnim putem (čl. 2. pod a) Direktive 2004/82/ EZ). Iako nas, dakle, naziv Direktive 2004/82/EZ upućuje na zaključak kako je riječ o obvezi dostave podataka o putnicima od strane prijevoznika u svim granama prometa, europski zakonodavac je definiranjem pojma prijevoznik ograničio primjenu rješenja Direktive 2004/82/EZ samo na zračne prijevoznike.

13 Direktivom 2004/82/EZ nije definiran pojam putnika.

14 Vasile, S. A.; Popescu, O., Smart Borders - Initiatives and Perspectives of the Information Flows Management within Schengen Area, Journal of Criminal Investigation, vol. 5, br. 1, 2012., str. 178.

15 Više vidi u: Ball, R., The Legitimacy of the European Union through Legal Rationality, Routledge, London - New York, 2013., str. 129.

16 Riječ je o osobnim podacima koji se odnose na pojedinca čiji je identitet utvrđen ili se identitet pojedinca može utvrditi (osoba koja se može identificirati izravno ili neizravno, osobito uz pomoć identifikatora kao što su ime, identifikacijski broj, podaci o lokaciji, mrežni identifikator ili uz pomoć jednog ili više čimbenika svojstvenih za fizički, fiziološki, genetski, mentalni, ekonomski, kulturni ili socijalni identitet tog pojedinca) - čl. 4. st. 1. pod 1. Uredbe (EU) 2016/679 Europskog parlamenta i Vijeća od 27. travnja 2016. o zaštiti pojedinaca u vezi s obradom osobnih podataka i o slobodnom kretanju takvih podataka te o stavljanju izvan snage Direktive 95/46/ EZ (Opća uredba o zaštiti podataka), Službeni list Europske unije, L 119, 4. svibnja 2016., str.1 - 88, dalje u tekstu: Uredba (EU) 2016/679. Više o zaštiti osobnih podataka putnika vidi u: Nino, M., The protection of personal data in the fight against terrorism - New perspectives of PNR European Union instruments in the light of the Treaty of Lisbon, Utrecht Law Journal, vol. 6, br. 1, 2010., str. 62 - 85.; Kraus, J.; Verner, T., Using sensor network for passengers prescreening in air transport, Journal of Transportation Security, vol. 9, br. 3-4, 2016., str. 119.

17 Riječ je o podacima koje i inače prikupljaju zračni prijenosnici koji prevoze putnike te su ih, na zahtjev tijela odgovornih za kontrolu osoba na vanjskim granicama, dužni prenijeti nakon završetka prijave putnika (vidi čl. 3. st. 1. Direktive 2004/82/ $\mathrm{EZ).}$ 
za identifikaciju osoba. ${ }^{18}$ Riječ je o sljedećim podacima: a) podacima navedenim u putnikovoj putnoj ispravi ${ }^{19}$ te b) podacima o samom prijevozu ${ }^{20}$ (API podaci ${ }^{21}$ ).

Osnovna svrha obavljanja takvih provjera jest izvršavanje provjere API podataka putnika iz trećih zemalja čak i prije nego što se putnici pojave na graničnom prijelazu ${ }^{22}$, čime se ostvaruje učinkovito sprječavanje nezakonite imigracije ${ }^{23}$, ujedno olakšavajući i ubrzavajući sigurnosne i granične provjere na vanjskim granicama država članica. Ipak, europski zakonodavac ne ograničava primjenu rješenja Direktive 2004/87/EZ isključivo u odnosu na putnike trećih zemalja koje prijevoznik prevozi na područje država članica. Iz odredbe čl. 3. st. 1. Direktive 2004/82/EZ jasno uočavamo kako je namjera europskog zakonodavca bila obvezati zračne prijevoznike, koji prevoze putnike na područje država članica EU-a, na prijenos podataka o putnicima neovisno o tome je li riječ o putnicima državljanima EU-a ili državljanima trećih zemalja. Također, važno je uočiti kako predmetna obveza zračnog prijevoznika postoji jedino u slučaju

18 Manteghi, M., Discussing Initiatives for an EU Passenger Name Records System in Light of Already Existing Data Processing Measures in the Field of Border Control, 2017., str. 3, https://ssrn.com/abstract=3082412 (15. siječnja 2019.). Više vidi u: Brouwer, E., Ignoring Dissent and Legality The EU's proposal to share the personal information of all passengers, CEPS, Liberty and Security in Europe, 2011., str. 3; De Hart, P.; Bellanova, R., Transatlantic Cooperation on Travelers' Data Processing: From Sorting Countries to Sorting Individuals, Migration Policy Institute, 2011., str. 6.

19 Riječ je o sljedećim putnikovim podacima: a) broj i vrsta putnog dokumenta koji se koristi, b) nacionalnost, c) puno ime i d) datum rođenja (čl. 3. st. 2. Direktive 2004/82/EZ). Više o API podacima koji su čitljivi iz putnikove putne isprave vidi u: Rossi Del Pozzo, F., International and EU legal frameworks of aviation security, u: Szyliowicz, J. S.; Zamparini, L. (ur.), Air Transport Security Issues Challenges and National Policies, Edward Elgar Publishing, 2018., str. 55.

20 Podaci o putnikovu prijevozu odnose se na sljedeće podatke: a) granični prijelaz na kojem se ulazi na državno područje države članice, b) oznaku prijevoza, c) vrijeme polaska i dolaska prijevoza, d) ukupan broj putnika koji se prevoze i e) prvo mjesto ukrcaja (čl. 3. st. 2. Direktive 2004/82/EZ).

${ }^{21}$ Advance Passenger Information, dalje u tekstu: API podaci. Više vidi u: Bigo, D.; Brouwer, E.; Carrera, S.; Guild, E.; Guittet, E. P.; Jeandesboz, J.; Ragazzi, F.; Scherrer, A., The EU Counter-Terrorism Policy Response to the Attacks in Paris: Towards an EU Security and Liberty Agenda, CEPS, Liberty and Security in Europe, br. 81, 2015., str. 9; De Hart; Bellanova, op. cit. u bilj. 18, str. 6.

22 Tako prema Guild, E.; Carrera, S.; Geyer, F., The Commission's New Border Package Does it take us one step closer to a "cyber-fortress Europe"?, CEPS Policy brief, br. 154, 2008., str. 4.

23 Više vidi u: Abeyratne, R., Convention on International Civil Aviation A Commentary, Springer, 2014., str. 365; Brouwer, op. cit. u bilj. 18, str. 3. 
kada postoji zahtjev nadležnih nacionalnih tijela za prijenosom API podataka o putnicima koje zračni prijevoznik prevozi. U tom slučaju zračni prijevoznik dužan je prenijeti API podatke službenom graničnom prijelazu preko kojeg će te osobe ući na državno područje države članice. Budući da je API podatke dopušteno koristiti samo na zahtjev tijela odgovornih za kontrolu osoba na vanjskim granicama, njihova razmjena između država članica je nedopuštena.

S obzirom na to da stalni rast broja putnika koji se na područje EU-a prevoze zračnim putem uvjetuje istodobno udovoljavanje zahtjevima za ubrzanjem provođenja postupaka graničnih kontrola i sprječavanje nezakonite imigracije, u ostvarenju tih ciljeva vrlo značajnu ulogu ima kvalitetan sustav prijenosa i obrade API podataka. Ispunjavanje prethodnih ciljeva nije jedinstveno ostvareno s obzirom na sadržajne razlike u implementaciji rješenja 2004/82/EZ u nacionalnim zakonodavstvima država članica EU-a i država koje su pridružene schengenskom prostoru ${ }^{24}$ (a nisu članice EU-a) te se na njih primjenjuju rješenja Direktive 2004/82/EZ. Godine 2012. provedena je evaluacija Direktive 2004/82/ $\mathrm{EZ}^{25}$, koja je istaknula pozitivne učinke izvršavanja obveze zračnog prijevoznika na prijenos API podataka - poduzimanje mjera zabrane ulaska u EU putnicima iz trećih zemalja, ali i drugih mjera koje su nadležna tijela izricala putnicima. ${ }^{26}$

24 Schengenski prostor obuhvaća prostor u kojemu se ne provode unutarnje granične kontrole, ali se provode kontrole na vanjskim granicama država schengenskog prostora (22 države članice EU-a: Austrija, Belgija, Češka, Danska, Estonija, Finska, Grčka, Francuska, Italija, Latvija, Litva, Luksemburg, Mađarska, Malta, Nizozemska, Njemačka, Poljska, Portugal, Slovenija, Slovačka, Španjolska i Švedska; uključujući i 4 države koje nisu članice EU-a: Island, Norveška, Švicarska, Lihtenštajn). Možemo uvidjeti kako sljedeće države članice EU-a nisu pridružene schengenskom prostoru: Irska, Ujedinjena Kraljevina, Bugarska, Hrvatska, Rumunjska i Cipar, ali na njih se također primjenjuju rješenja Direktive 2004/82/EZ. Više vidi u: Europska komisija, Europa bez granica - Schengenski prostor, str. 2, http://publications.europa.eu/ resource/cellar/09fcf4lf-ffc4-472a-a573-b46f0b34119e.0001.01/DOC_1 (16. listopada 2019.).

25 Canetta, E.; Korpelainen, S.; Mortera, C.; Robson, L.; Minkova, V.; Damianakis, K., Evaluation on the implementation and functioning of the obligation of carriers to communicate passenger data set up by Directive 2004/82, Final Report for Directorate-General for Home Affairs, https://ec.europa.eu/home-affairs/sites/homeaffairs/files/elibrary/ documents/policies/irregular-migration-return/return readmission/docs/evaluation_of_the_api_directive_en.pdf (11. listopada 2019.).

26 U razdoblju 2010. - 2011. austrijska nadležna tijela poduzela su mjere protiv $0,4 \%$ svih putnika na međunarodnim letovima čije su API podatke prikupili. U razdoblju 2008. - 2011. njemačka nadležna tijela su identificirala na temelju API podataka čak 7 \% letova na kojima je bila najmanje jedna tražena osoba. U Ujedinjenoj Kraljevini, na temelju API podataka, 2322 osobama zabranjen je ulazak (u razdoblju 
No, izvršavanje obveze prijenosa API podataka predstavljalo je ujedno i negativne gospodarske učinke za zračne prijevoznike. Naime, primjena Direktive 2004/82/ EZ rezultirala je godišnjim financijskim troškovima prijevoznika u omjeru od 500.000 eura za manje zračne prijevoznike do čak 2.000 .000 eura prosječno za veće zračne prijevoznike. ${ }^{27}$ Značajni financijski troškovi zračnih prijevoznika u vezi sa stvaranjem i osuvremenjivanjem tehničkih sustava prikupljanja i prijenosa API podataka dodatno su naglašeni i odredbom čl. 4. st. 1. Direktive 2004/82/ EZ o obvezi država članica propisati novčane sankcije za zračne prijevoznike koji vlastitom krivnjom ne prenesu podatke ili prenesu nepotpune ili netočne podatke. ${ }^{28}$ Do svibnja 2012. države članice izrekle su novčane sankcije zračnim prijevoznicima u iznosu od 1,7 milijuna eura. ${ }^{29}$

\section{I. Implementacija rješenja Direktive 2004/82/EZ u hrvatski pravni sustav}

Prema odredbi čl. 7. st. 1. Direktive 2004/82/EZ države članice bile su dužne poduzeti potrebne mjere kako bi se uskladile s odredbama ove Direktive najkasnije do 5. rujna 2006. godine. ${ }^{30}$ Predmetni rok za prenošenje prava EU-a u nacionalna zakonodavstva produžen je za Rumunjsku i Bugarsku ${ }^{31}$ te $\mathrm{RH} .{ }^{32}$ U RH još 2012. nisu bili ostvareni tehnički preduvjeti i odabrana tehnologija

2008. - 2011.) te je ukupno vraćeno 17.000 osoba (u razdoblju 2005. - 2011.). Od 2010. - 2011. njemačka nadležna tijela zabilježila su 12.332 slučaja u kojima su tijela nadležna za upravljanje granicama, na temelju API podataka, poduzela mjere protiv putnika na međunarodnim letovima (u Italiji, samo u 2011. - 85.222 slučaja) - ibid., str. 7, 9.

27 Ibid., str. 8.

28 Navedena rješenja propisuju dužnost država članica propisati mjere kojima se osigurava da najviši iznos sankcija ne bude manji od 5000 eura, odnosno da najniži iznos sankcija ne bude manji od 3000 eura za svako putovanje za koje prijevoznici nisu dostavili podatke o putnicima ili ti podaci nisu točno dostavljeni.

29 Canetta et al., op. cit. u bilj. 25, str. 9.

30 Više o nacionalnom prenošenju odredaba Direktive 2004/82/EZ u državama članicama vidi $u$ : Nacionalne mjere za prenošenje koje su države članice dostavile $u$ vezi sa sljedećom direktivom: Direktiva Vijeća 2004/82/EZ od 29. travnja 2004. o obvezi prijevoznika na dostavljanje podataka o putnicima, Službeni list Europske unije, L 261, 6. kolovoza 2004., str. $24-27$.

31 Za Rumunjsku i Bugarsku rok prenošenja bio je 1. siječnja 2007. godine (dan kada su navedene države postale članice EU-a).

32 Za RH je rok prenošenja bio 1. srpnja 2013. godine (dan kada je RH postala članica EU-a). 
primjene API podataka od zračnih prijevoznika te je konstatirano kako od 27 država članica EU-a čak 15 država nije primjenjivalo API te da za RH nije izgledno njegovo uvođenje prije pristupanja EU-u ${ }^{33}$, nego eventualno tek prilikom njezina pridruživanja schengenskom prostoru. Ipak, i prije pridruživanja RH u schengenski prostor ${ }^{34}$, tijekom 2013. godine, Nacionalno povjerenstvo za olakšice razmatralo je sustav API podataka u cilju unaprjeđenja kontrole ulaska putnika zračnim prijevozom u RH. Rješenja Direktive 2004/82/EZ prenesena su u pravni poredak RH stupanjem na snagu Zakona o nadzoru državne granice iz 2013. ${ }^{35}$, koji uređuje nadzor državne granice, poslove granične policije u unutrašnjosti države, međunarodnu graničnu policijsku suradnju i suradnju službi na državnoj granici. ${ }^{36}$

Obveze prijevoznika u zračnom prometu ${ }^{37}$ pravno su normirane odredbom čl. 24. Zakona o nadzoru državne granice prema kojoj je zračni prijevoznik dužan: a) odmah po završetku prijave putnika ${ }^{38}$ za let tijelu nadležnom za kontrolu prelaska državne granice na graničnom prijelazu na kojem će putnici ući u $\mathrm{RH}^{39}$ dostaviti potpune i točne podatke o putnicima ${ }^{40}$, b) o dostavi podataka prije-

33 Godišnje izvješće o radu Nacionalnog povjerenstva za olakšice za 2012. god., 5. ožujka 2013., str. 2 - 3, https://vlada.gov.hr/UserDocsImages//2016/Sjednice/Arhiva//92.\%20-\%20 17c.pdf (11. veljače 2019.).

34 Do dana predaje rada $\mathrm{RH}$ još nije ušla u schengenski prostor.

35 Zakon o nadzoru državne granice, Narodne novine, br. 83/2013, stupio na snagu 2. srpnja 2013. godine. Predmetni zakon izmijenjen je 2016. godine - vidi Zakon o dopuni Zakona o nadzoru državne granice, Narodne novine, br. 27/2016, dalje u tekstu: Zakon o nadzoru državne granice. Čl. 1. Zakona o nadzoru državne granice. Zakon o nadzoru državne granice ne sadržava definiciju prijevoznika iako je predmetna definicija sadržana u čl. 2. pod a) Direktive 2004/82/EZ (vidi bilj. 12).

38 Po uzoru na rješenja Direktive 2004/82/EZ hrvatski zakonodavac ne definira pojam putnika (vidi bilj. 13).

39 Riječ je o tijelima nadležnim za kontrolu prelaska državne granice na području graničnih prijelaza na aerodromima u RH (više vidi čl. 4. st. 1. pod 2. Zakona o nadzoru državne granice).

40 Riječ je o sljedećim, taksativno navedenim, podacima o putnicima: broj i vrsta putne isprave, državljanstvo, ime i prezime, datum rođenja, naziv graničnog prijelaza na kojem će ući u RH, oznaka leta, vrijeme polaska i dolaska, ukupan broj putnika, prvo mjesto ukrcaja (čl. 24. st. 2. Zakona o nadzoru državne granice). Pravna formulacija hrvatskog zakonodavca o obvezi zračnih prijevoznika na dostavu "potpunih i točnih" podataka o putnicima (čl. 24. st. 2. Zakona o nadzoru državne granice) nije korištena u rješenjima Direktive 2004/82/EZ (vidi čl. 3. st. 1. Direktive 2004/82/EZ). 
voznik je dužan na prikladan način obavijestiti putnika ${ }^{41}$ i c) izbrisati podatke u roku od 24 sata od vremena pristajanja zrakoplova u zračnoj luci na kojoj je obavljena ulazna granična kontrola. ${ }^{42}$ Prema odredbi čl. 24. st. 3. Zakona o nadzoru državne granice podaci se prikupljaju i dostavljaju elektroničkim putem, sukladno tehničkim mogućnostima. ${ }^{43} \mathrm{U}$ slučaju nepridržavanja zakonom propisane obveze zračnog prijevoznika iz čl. 24. Zakona o nadzoru državne granice, hrvatski zakonodavac propisao je prekršajnu odgovornost zračnog prijevoznika. ${ }^{44}$

$\mathrm{Na}$ temelju rješenja poglavlja 8., standarda 8.17. Priloga 9. "Olakšice" Konvencije o međunarodnom civilnom zrakoplovstvu iz 1944. godine ${ }^{46}$, u cilju uspostave jednostavnijih postupaka i dokumentacije vezano za kretanje putnika u zračnom prijevozu ${ }^{47}$, odredbom čl. 37. st. 1. Zakona o zračnom prometu ${ }^{48}$

41 Ova obveza prijevoznika odgovara rješenju čl. 6. st. 2. Direktive 2004/82/EZ.

42 Ova obveza prijevoznika odgovara rješenju čl. 6. st. 1. Direktive 2004/82/EZ.

43 Možemo uočiti kako se hrvatski zakonodavac odlučio isključivo za elektroničko prikupljanje i prijenos API podataka. Europski zakonodavac je čl. 6. st. 1. Direktive 2004/82/EZ propisao dužnost država članica osigurati da prijevoznici prikupljaju i prenose API podatke elektroničkim putem ili nekim drugim prikladnim sredstvom (u slučaju nemogućnosti elektroničkog prijenosa).

44 Prema odredbi čl. 46. st. 2. Zakona o nadzoru državne granice novčanom kaznom od 22.000 do 40.000 kuna kaznit će se za prekršaj pravna osoba koja u svojstvu zračnog prijevoznika dostavi netočne ili nepotpune podatke ili ne dostavi podatke o putnicima (čl. 24. st. 2. Zakona o nadzoru državne granice). Ta odredba odgovara rješenju čl. 4. st. 1. Direktive 2004/82/EZ (vidi bilj. 28).

45 Annex 9 to the Convention on International Civil Aviation, 15. izdanje, 23. listopada 2017., u primjeni od 23. veljače 2018., dalje u tekstu: Prilog 9. Čikaške konvencije, https:// www.icao.int/WACAF/Documents/Meetings/2018/FAL-IMPLEMENTATION/ an09_cons.pdf (19. ožujka 2019.).

46 Konvencija o međunarodnom civilnom zrakoplovstvu iz 1944. stupila je na snagu 4. travnja 1947. godine, dalje u tekstu: Čikaška konvencija. Čikašku konvenciju potpisale su 52 države, a do ožujka 2019. prihvatile su je 192 države svijeta (više vidi https://www. icao.int/secretariat/legal/List\%20of\%20Parties/Chicago_EN.pdf, 13. ožujka 2019.). Detaljnije o Čikaškoj konvenciji vidi u: Hlača, V., Hrvatsko prometno pravo i međunarodne konvencije, Pravni fakultet u Rijeci, Rijeka, 2000., str. 132; Grabovac, I.; Kaštela, S., Međunarodni i nacionalni izvori hrvatskoga prometnog prava, HAZU - Književni krug, Zagreb - Split, 2013., str. 230 - 232; Weber, L., The Chicago Convention, u: Dempsey, P. S.; Jakhu, R. S. (ur.), Routledge Handbook of Public Aviation Law, Routledge, 2016., str. 9 - 32.

47 Vidi Rossi Del Pozzo, F., EU Legal Framework for Safeguarding Air Passenger Rights, Springer, 2014., str. 100.

48 Zakon o zračnom prometu, Narodne novine, br. 69/2009, 84/2011, 54/2013, 127/2013, 92/2014. Detaljnije vidi Bolanča, D., Prometno pravo Republike Hrvatske, Pravni fakultet u Splitu, Split, 2016., str. $396-405$. 
propisano je kako Vlada RH osniva Nacionalno povjerenstvo za olakšice ${ }^{49}$ te na prijedlog povjerenstva donosi Nacionalni program za olakšice. ${ }^{50}$ Dana 1. listopada 2015. Vlada RH donijela je Nacionalni program za olakšice ${ }^{51}$, koji ima cilj pojednostaviti procedure i dokumentaciju koji se odnose na kretanje zrakoplova i članova posade, putnike i njihovu prtljagu te učiniti sve kako bi se ubrzale aerodromske procedure i u najvećoj mogućoj mjeri smanjio broj dokumenata koristeći informatičku tehnologiju. Suradnja s prijevoznicima u zračnom prometu vezano uz obvezu prijevoznika o dostavi podataka o putnicima, kao posebna zadaća, stavljena je u nadležnost Ministarstva unutarnjih poslova Republike Hrvatske..$^{52}$ Implementacija dostave API podataka počela je u RH u ožujku 2017. godine (u Zračnoj luci Franjo Tuđman na međunarodnom graničnom prijelazu za zračni promet Zagreb), a u studenom 2017. godine nastavljena je i u ostalim zračnim lukama u RH. ${ }^{53}$

\section{OBVEZA ZRAČNIH PRIJEVOZNIKA NA PRIJENOS PODATAKA IZ EVIDENCIJE PODATAKA O PUTNICIMA PREMA RJEŠENJIMA DIREKTIVE (EU) 2016/681}

Prijetnja prekograničnim terorizmom upućuje na nužnost suradnje država članica, pa i glede učinkovite razmjene informacija koje nadležna tijela smatraju relevantnim za sprječavanje, otkrivanje, istragu i kazneni progon kaznenih djela terorizma. ${ }^{54} \mathrm{U}$ cilju uspostave pravnog okvira prijenosa podataka o putnicima

49 Vidi Odluku o osnivanju Nacionalnog povjerenstva za olakšice, Narodne novine, br. $129 / 2017$.

50 Čl. 37. st. 3. Zakona o zračnom prometu.

51 Vidi Odluku o donošenju Nacionalnog programa za olakšice, Narodne novine, br. 105/2015, dalje u tekstu: Nacionalni program za olakšice.

52 Ministarstvo unutarnjih poslova Republike Hrvatske, dalje u tekstu: MUP.

53 Vlada RH, 12. Izvješće o provedbi Strategije integriranog upravljanja granicom Republike Hrvatske za 2017. godinu, srpanj 2018. god., str. 59, https:/vlada.gov.hr/UserDocsImages//2016/Sjednice/2018/10\%20listopad/118\%20sjednica\%20VRH/Novo//118\%20 -\%2013.pdf (14. lipnja 2019.).

54 Minimalna pravila u pogledu definicije kaznenih djela i sankcija u području kaznenih djela terorizma, kaznenih djela povezanih s terorističkom skupinom i kaznenih djela povezanih s terorističkim aktivnostima, kao i mjere zaštite žrtava terorizma te potpore i pomoći tim žrtvama utvrđena su Direktivom (EU) 2017/541 Europskog parlamenta i Vijeća od 15. ožujka 2017. o suzbijanju terorizma i zamjeni Okvirne odluke Vijeća 2002/475/PUP i o izmjeni Odluke Vijeća 2005/671/PUP, Službeni list Europske unije, L 88, 31. ožujka 2017., str. 6 - 21. 
u zračnom prijevozu te zaštite podataka iz evidencije podataka o putnicima $u$ pogledu njihove obrade koju, nakon terorističkih napada u Parizu u studenom 2015., dana 27. travnja 2016. Europski parlament i Vijeće Europske unije donijeli su Direktivu (EU) 2016/681 o uporabi podataka iz evidencije podataka o putnicima (PNR) u svrhu sprečavanja, otkrivanja, istrage i kaznenog progona kaznenih djela terorizma ${ }^{55}$ i teških kaznenih djela. ${ }^{56}$ Direktiva (EU) 2016/681 pravno uređuje pitanja prijenosa i obrade podataka o putnicima ${ }^{57}$ iz evidencije podataka o putnicima. ${ }^{58}$

\subsection{Prijenos podataka o putnicima iz PNR-a}

Radi sprječavanja, otkrivanja, istrage i kaznenog progona kaznenih djela terorizma i teških kaznenih djela ${ }^{59}$ odredbom čl. 1. st. 1. pod a) Direktive (EU)

55 Kaznena djela terorizma kaznena su djela u skladu s nacionalnim pravom iz članaka od 1. do 4. Okvirne odluke Vijeća od 13. lipnja 2002. o suzbijanju terorizma - 2002/475/PUP, Službeni list Europske unije, L 164, 22. lipnja 2002., str. 3 - 7 (čl.

3. st. 1. t. 8. Direktive (EU) 2016/681).

56 Direktivu (EU) 2016/681 o uporabi podataka iz evidencije podataka o putnicima (PNR) u svrhu sprečavanja, otkrivanja, istrage i kaznenog progona kaznenih djela terorizma i teških kaznenih djela, Službeni list Europske unije, L 119, 4. svibnja 2016., str. 132 - 149, na snazi od 24. svibnja 2016. godine, dalje u tekstu: Direktiva (EU) 2016/681.

57 Putnik je svaka osoba, uključujući transferne ili tranzitne putnike, izuzev članova posade, koja se prevozi ili će se prevesti u zrakoplovu uz pristanak zračnog prijevoznika, vidljivog iz upisa osoba na popis putnika (čl. 3. st. 1. t. 4. Direktive (EU) 2016/681). Više o postupcima prijenosa i obrade podataka o putnicima vidi u: De Hart; Bellanova, op. cit. u bilj. 18, str. 5.

58 Evidencija podataka o putnicima (Passenger Name Record, dalje u tekstu: PNR) znači evidencija zahtjeva u vezi s putovanjem svakog putnika koja sadržava informacije potrebne za obradu i kontrolu rezervacija od strane uključenih zračnih prijevoznika i onih koji obavljaju rezervacije za svako putovanje rezervirano od strane neke osobe ili u njezino ime, neovisno o tome čini li sastavni dio sustava rezervacija, sustava kontrole odlazaka, koji služi prijavi putnika na letove ili jednakovrijednog sustava s istim funkcijama (čl. 3. st. 1. t. 5. Direktive (EU) 2016/681).

59 Teška kaznena djela definirana su kao ona koja su kažnjiva kaznom zatvora ili mjerom oduzimanja slobode od najmanje tri godine u skladu s nacionalnim pravom države članice, a navedena su u Prilogu II. Direktive (EU) 2016/681 (čl. 3. st. 1. t. 9. Direktive (EU) 2016/681). Riječ je o sljedećim kaznenim djelima: 1. pripadanje zločinačkoj organizaciji; 2. trgovanje ljudima; 3. spolno iskorištavanje djece i dječja pornografija; 4. nedopušteno trgovanje opojnim drogama i psihotropnim tvarima; 5. nedopuštena trgovina oružjem, streljivom i eksplozivima; 6. korupcija; 7. pri- 
2016/681 propisana je dužnost zračnih prijevoznika ${ }^{60}$ provesti prijenos podataka o putnicima iz PNR-a ${ }^{61}$ ako je riječ o putnicima na letovima između EU-a i

jevara, uključujući i prijevaru koja ugrožava financijske interese Unije; 8. pranje prihoda stečenog kaznenim djelom i krivotvorenje novca, uključujući euro; 9. računalni kriminal/kiberkriminalitet; 10. kaznena djela protiv okoliša, uključujući i nedopuštenu trgovinu ugroženim životinjskim vrstama te ugroženim biljnim vrstama i sortama; 11. omogućavanje neovlaštenog ulaska i boravka; 12. ubojstvo, teška tjelesna ozljeda; 13. nezakonita trgovina ljudskim organima i tkivima; 14. otmica, protupravno oduzimanje slobode i držanje talaca; 15. organizirana i oružana pljačka; 16. nedopuštena trgovina kulturnim dobrima, uključujući starine i umjetnička djela; 17. krivotvorenje i piratstvo proizvoda; 18. krivotvorenje administrativnih isprava i trgovina njima; 19. nezakonita trgovina hormonskim tvarima i drugim poticateljima rasta; 20 . nedopuštena trgovina nuklearnim ili radioaktivnim materijalima; 21. silovanje; 22. kaznena djela iz nadležnosti Međunarodnog kaznenog suda; 23. protupravno oduzimanje zrakoplova ili brodova; 24. sabotaža; 25. trgovina ukradenim vozilima; 26. industrijska špijunaža. Više o neprimjerenosti PNR sustava i činjenici da nije nužno potreban u svrhu borbe protiv terorizma i drugih teških kaznenih djela vidi Bigo et al., op. cit. u bilj. 21, str. 16.

Zračni prijevoznik je poduzeće za zračni prijevoz s važećom dozvolom za obavljanje djelatnosti ili jednakovrijednom dozvolom za obavljanje prijevoza putnika zrakom (čl. 3. st. 1. pod 1. Direktive (EU) 2016/681).

${ }_{61}$ Riječ je o sljedećim podacima: 1. kod evidencije PNR-a; 2. datum rezervacije/izdavanja karte; 3. predviđen(i) datum(i) putovanja; 4. ime(na); 5. adresa i kontaktni podaci (telefonski broj, adresa e-pošte); 6. svi podaci o načinu plaćanja, uključujući adresu za slanje računa; 7. cjeloviti plan puta za konkretni PNR; 8. podaci o programima vjernosti; 9. putnička agencija / putnički agent; 10. status putnika, uključujući informacije o potvrdi, prijavi na let, neprijavljivanju na let ili prijavi u posljednjem trenutku bez rezervacije; 11. razdijeljene/podijeljene informacije iz PNR-a; 12. opće primjedbe (uključujući sve dostupne informacije o maloljetnim putnicima bez pratnje mlađima od 18 godina, kao što su ime i spol maloljetnika, dob, jezik/jezici koje govori, ime i kontaktni podaci pratitelja na polasku i kako je povezan s maloljetnikom, ime i kontaktni podaci pratitelja na dolasku i kako je povezan s maloljetnikom, agent na polasku i dolasku); 13. informacije s putne karte, uključujući broj karte, datum izdavanja karte, jednosmjerne karte, polja elektronskih karata koja se odnose na cijenu (Automated Ticket Fare Quote); 14. broj sjedala i ostale informacije o sjedalu; 15. informacije o zajedničkom letu; 16. sve informacije koje se odnose na prtljagu; 17. broj i imena drugih putnika iz PNR-a; 18. sve informacije o putnicima koje će prevoziti (API) (uključujući vrstu, broj, zemlju izdavanja i datum isteka roka važenja bilo kojeg osobnog dokumenta, državljanstvo, prezime, ime, spol, datum rođenja, zračnog prijevoznika, broj leta, datum polaska, datum dolaska, zračnu luku polaska, zračnu luku dolaska, vrijeme polaska i vrijeme dolaska); 19. sve kronološke izmjene podataka iz PNR-a navedene u točkama od 1. do 18. (tako prema Prilogu I. "Podaci iz evidencije podataka o putnicima kako ih prikupljaju zračni prijevoznici" Direktive (EU) 2016/681, dalje u tekstu: Prilog I. Direktive (EU) 2016/681). 
trećih zemalja. ${ }^{62}$ Ipak, europski zakonodavac propisao je pravo država članica primijeniti rješenja Direktive (EU) 2016/681 i na letove unutar EU-a ${ }^{63}$, odnosno samo na odabrane letove unutar EU-a (čl. 2. st. 3. Direktive (EU) 2016/681). ${ }^{64}$

Zračni prijevoznici prikupljaju podatke o putnicima iz PNR-a na temelju podataka o rezervacijama (prilikom rezervacije karata) i podataka dostupnih prilikom prijave putnika na let (check-in). Važno je uočiti kako se PNR podaci mogu razlikovati kod svakog zračnog prijevoznika i ne moraju uvijek uključivati iste vrste podataka. ${ }^{65}$ Podaci koje zračni prijevoznici prikupljaju odnose se na osobne podatke koje sami putnici prijavljuju zračnim prijevoznicima (uobičajeno oni obuhvaćaju i API podatke) ${ }^{66}$ te oni nisu službeni podaci kao u slučaju API podataka. ${ }^{67}$ Svakako je važno kako su podaci iz PNR-a od interesa nadležnih tijela kako bi mogli identificirati one putnike koji predstavljaju opasnost unutarnjoj sigurnosti EU-a ${ }^{68}$, no PNR podaci se ne podudaraju uvijek s osobom koju zračni prijevoznik prevozi. ${ }^{69}$

62 Let između EU-a i trećih zemalja je svaki redoviti ili izvanredni let zračnog prijevoznika čije se polazište nalazi u trećoj zemlji, a odredište na državnom području države članice ili čije se polazište nalazi na državnom području države članice, a odredište u trećoj zemlji, uključujući u oba slučaja letove sa zaustavljanjima na državnom području država članica ili trećih zemalja (čl. 3. st. 1. t. 2. Direktive (EU) 2016/681).

63 Let unutar EU-a svaki je redoviti ili izvanredni let zračnog prijevoznika čije se polazište nalazi na državnom području države članice, a odredište na državnom području jedne države članice ili više njih, bez zaustavljanja na državnom području ili u zračnim lukama treće zemlje (čl. 3. st. 1. t. 3. Direktive (EU) 2016/681). O odluci države članice o primjeni Direktive (EU) 2016/681 na letove unutar EU-a država članica je dužna, u pisanom obliku, obavijestiti Komisiju koja će obavijest o toj odluci objaviti u Službenom listu Europske unije (čl. 2. st. 1. Direktive (EU) 2016/681).

64 Pri donošenju predmetne odluke država članica odabire letove koje smatra potrebnima kako bi ostvarila ciljeve Direktive (EU) 2016/681. Europski zakonodavac u ovom slučaju nije propisao dužnost obavještavanja Europske komisije o predmetnoj odluci kao ni dužnost njezine objave u Službenom listu Europske unije (više vidi čl. 2. st. 3. Direktive (EU) 2016/681).

Brouwer, op. cit. u bilj. 18, str. 3.

De Hart; Bellanova, op. cit. u bilj. 18, str. 6; Boehm, F., Confusing fundamental rights protection in Europe: Loopholes in Europe's fundamental rights protection exemplified on European data protection rules, Faculty of Law, Economics and Finance, 2009., str. 12, https://ssrn.com/abstract=1348472 (11. prosinca 2018.).

67 Više vidi Bigo et al., op. cit. u bilj. 21, str. 9.

68 Preambula, pod 15. Direktive (EU) 2016/681.

Brouwer, op. cit. u bilj. 18, str. 3. 
Obveze zračnih prijevoznika u pogledu prijenosa podataka iz PNR-a normirane su detaljnije odredbom čl. 8. Direktive (EU) 2016/681 na temelju koje su države članice dužne poduzeti potrebne mjere kako bi osigurale da zračni prijevoznici podatke iz PNR-a prenesu ("metodom unošenja”) ${ }^{70} \mathrm{u}$ bazu podataka odjela za informacije (PIU) ${ }^{71}$ države članice na čijem se državnom području nalazi polazište ili odredište leta. ${ }^{72}$ Možemo uočiti kako su podatke iz PNR-a dužni sustavno prenositi, nadležnim tijelima, zračni prijevoznici dok do prenošenja API podataka dolazi samo na zahtjev tijela odgovornih za kontrolu osoba na vanjskim granicama. ${ }^{73}$ Podatke iz PNR-a zračni prijevoznici prenose elektroničkim putem upotrebljavajući zajedničke protokole i podržane formate za prijenos podataka ${ }^{74}$ u sljedećim rokovima: a) 24 do 48 sati prije zakazanog

70 Metoda unošenja je metoda kojom zračni prijevoznici prenose podatke iz PNR-a u bazu podataka tijela koje ih zahtijeva (čl. 3. st. 1. t. 7. Direktive (EU) 2016/681). Riječ je o metodi kojom sami zračni prijevoznici prenose podatke iz PNR-a te, zadrŽavajući kontrolu nad podacima koje prenose, pružaju višu razinu zaštite podataka.

71 Odjel za informacije (Passenger Information Unit, dalje u tekstu: PIU), kao tijelo nadležno za sprječavanje, otkrivanje, istragu ili kazneni progon kaznenih djela terorizma i teških kaznenih djela, mora osnovati svaka država članica ili ga država članica mora odrediti unutar ogranka tijela nadležnog za sprječavanje, otkrivanje, istragu ili kazneni progon kaznenih djela terorizma i teških kaznenih djela (vidi čl. 4. st. 1. Direktive (EU) 2016/681).

72 Kada je riječ o zajedničkim letovima (code-sharing) jednog zračnog prijevoznika ili više njih, zračni prijevoznik koji obavlja let odgovoran je za prijenos podatka iz PNR-a svih putnika na letu. Kada let između EU-a i trećih zemalja ima jedno zaustavljanje ili više njih u zračnim lukama država članica, zračni prijevoznici prenose podatke iz PNR-a u pogledu svih putnika PIU-ovima svih uključenih država članica. To se također primjenjuje kada let unutar EU-a ima jedno zaustavljanje ili više njih u zračnim lukama različitih država članica, ali samo u odnosu na države članice koje prikupljaju podatke iz PNR-a dobivene na temelju letova unutar EU-a. - čl. 8. st. 1. Direktive (EU) 2016/681.

73 Detaljnije vidi Leonard, S., The use and effectiveness of migration controls as a counter-terrorism instrument in the European Union, University of Salford, Manchester, 2010., str. 43, http://usir.salford.ac.uk/18771/1/SL_CEJISS_border_controls_CT.pdf (16. studenoga 2018.).

74 Svi prijenosi podataka iz PNR-a koje zračni prijevoznici izvrše PIU-ovima obavljaju se elektroničkim putem, koji pruža dovoljna jamstva u pogledu tehničkih mjera sigurnosti i organizacijskih mjera koje se odnose na provođenje obrade. U slučaju tehničkog kvara podaci iz PNR-a mogu se prenositi bilo kojim drugim odgovarajućim sredstvima, pod pretpostavkom da pritom zadrže jednaku razinu sigurnosti i budu u potpunosti u skladu s pravom Unije o zaštiti podataka (čl. 16. st. 1. Direktive (EU) 2016/681). Više o popisu zajedničkih formata podataka za prijenos podataka iz PNR-a te protokola za prijenos podataka iz PNR-a vidi Provedbenu odluku Ko- 
vremena polaska zrakoplova te b) odmah po zatvaranju leta, tj. kada su se putnici ukrcali u zrakoplov koji se sprema za polazak i kada se putnici više ne mogu ukrcati ni iskrcati. ${ }^{75}$

Ako podaci iz PNR-a koje zračni prijevoznici prenose sadržavaju podatke koji nisu navedeni u Prilogu I. Direktive (EU) 2016/681, PIU je dužan te podatke odmah po primitku trajno izbrisati. ${ }^{76}$ Preostale podatke iz PNR-a o putnicima na letovima između EU-a i trećih zemalja zračni prijevoznik je dužan prenijeti u bazu podataka PIU-a države članice na čijem se državnom području nalazi polazište ili odredište leta, a daljnja je nadležnost PIU-a prikupiti, pohraniti i obraditi navedene podatke. ${ }^{77}$ Troškove uporabe i čuvanja podataka iz PNR-a trebaju snositi države članice. ${ }^{78}$

Kada zračni prijevoznici prikupljaju API podatke o putnicima koje će prevoziti, uključujući podatke o vrsti, broju, zemlji izdavanja i datumu isteka roka važenja bilo kojeg osobnog dokumenta, državljanstvu, prezimenu, imenu, spolu, datumu rođenja, zračnom prijevozniku, broju leta, datumu polaska, datumu dolaska, zračnoj luci polaska, zračnoj luci dolaska, vremenu polaska i vremenu dolaska ${ }^{79}$ (ali te podatke ne zadržavaju putem istih tehničkih sredstava kao druge podatke iz PNR-a) - države članice dužne su donijeti potrebne mjere kako bi se osiguralo da zračni prijevoznici te podatke također prenose "metodom unošenja” PIU-u države članice na čijem se državnom području nalazi polazište ili odredište leta. ${ }^{80} \mathrm{Za}$ zračne prijevoznike koji ne prenose podatke u skladu s odredbom čl.8. Direktive (EU) 2016/681 ili ih ne prenose u propisanom formatu - države članice dužne su propisati pravila o sankcijama koja će uključivati financijske sankcije za navedene zračne prijevoznike. ${ }^{81}$

misije (EU) 2017/759 od 28. travnja 2017. o zajedničkim protokolima i formatima podataka koje zračni prijevoznici trebaju upotrebljavati pri prijenosu podataka iz evidencije podataka o putnicima (PNR) odjelima za informacije o putnicima, Službeni list Europske unije, L 113, 29. travnja 2017., str. 48 - 51.

75 Čl. 8. st. 3. Direktive (EU) 2016/681.

Čl. 6. st. 1. Direktive (EU) 2016/681.

Čl. 4. st. 2. pod a) Direktive (EU) 2016/681.

Vidi Preambula Direktive (EU) 2016/681, pod 14.

Vidi Prilog I. Direktive (EU) 2016/681 pod 18.

Čl. 8. st. 2. Direktive (EU) 2016/681.

Čl. 14. st. 2. Direktive (EU) 2016/681. 


\subsection{Implementacija rješenja Direktive (EU) 2016/681 u hrvatski pravni sustav}

Stupanjem na snagu Direktive (EU) 2016/681 došlo je do jedinstvene izmjene podataka u EU-u između zračnih prijevoznika i PIU-a. ${ }^{82}$ Prema odredbi čl. 18. st. 1. Direktive (EU) 2016/681 države članice bile su dužne uskladiti nacionalna zakonodavstva s njezinim rješenjima do 25. svibnja 2018. godine. U tom roku većina država članica prenijela je rješenja europskog prava u nacionalno zakonodavstvo. ${ }^{83} \mathrm{RH}$ je jedna od prvih osam država članica koje su u svoje nacionalno zakonodavstvo preuzele Direktivu (EU) 2016/681 ${ }^{84}$ donošenjem Zakona o prijenosu i obradi podataka o putnicima u zračnom prometu u svrhu sprječavanja, otkrivanja, istraživanja i vođenja kaznenog postupka za kaznena djela terorizma i druga teška kaznena djela iz 2018. godine..$^{85}$ Ovaj Zakon primjenjuje se na sve letove zračnog prijevoznika ${ }^{86} \mathrm{u}$ hrvatskom zračnom prostoru ${ }^{87}$ te letove kojima je polazište $\mathrm{u}$ RH, a odredište u drugoj državi ili kojima je polazište u drugoj

82 Boehm, F., Tit for tat - Europe's revenge for the Canadian and US-American PNR systems? The envisaged European model of analyzing flight passenger data, ERA Forum, vol. 11, br. 2, 2010., str. 254. Više vidi u: Wilson, K., "Gone With the Wind?: The Inherent Conflict between API/PNR and Privacy Rights in an Increasingly Security-Conscious World”, Air and Space Law, vol. 41, br. 3, 2016., str. 229 - 264.

83 Države članice EU-a koje nisu do 25. svibnja 2018. prenijele rješenja Direktive (EU) 2016/681 u nacionalna zakonodavstva su: Danska, Španjolska, Nizozemska, Portugal i Finska (tako prema podacima Nacionalne mjere za prenošenje koje su države članice dostavile u vezi s Direktivom (EU) 2016/681, Službeni list Europske unije, L 119, 4. svibnja 2016., str. 132 - 149.

84 Tako prema Vlada Republike Hrvatske, Izvješće o provedbi Strategije nacionalne sigurnosti Republike Hrvatske, 15. siječnja 2019., str. 13, https:/vlada.gov.hr/UserDocsImages//Sjednice/2019/...//138\%20-\%203.pdf (10. listopada 2019.).

85 Zakon o prijenosu i obradi podataka o putnicima u zračnom prometu u svrhu sprječavanja, otkrivanja, istraživanja i vođenja kaznenog postupka za kaznena djela terorizma i druga teška kaznena djela, Narodne novine, br. 46/2018, na snazi od 26. svibnja 2018., dalje u tekstu: Zakon iz 2018. godine. Popis 26 kaznenih djela u čije svrhe sprječavanja, otkrivanja, provođenja istraživanja i vođenja kaznenog postupka je dopušteno obrađivati podatke o putnicima odgovara rješenjima Direktive (EU) 2016/681 (vidi bilj. 59).

86 Zračni prijevoznik je poduzetnik koji posjeduje valjanu Operativnu licenciju ili jednakovrijedan dokument kojim je ovlašten za obavljanje komercijalnog zračnog prijevoza (čl. 3. st. 1. t. 5. Zakona iz 2018. godine). Usporedi bilj. 60.

87 Hrvatski zračni prostor je prostor iznad kopna i teritorijalnog mora RH (čl. 1. st. 4. Zakona o zračnom prometu). 
državi, a odredište ili međuslijetanje u RH. ${ }^{88}$ Prikupljanje i obrada podataka o putnicima ${ }^{89}$ u zračnom prometu u nadležnosti je jedinice za informacije o putnicima (PIU).$^{90}$ Domaća nadležna tijela za traženje ili primanje podataka o putnicima ili rezultata obrade tih podataka (u svrhe daljnjeg ispitivanja tih podataka ili poduzimanja odgovarajućih mjera u okviru svog djelokruga) su: policija, vojna policija, Sigurnosno-obavještajna agencija, Vojna sigurnosno-obavještajna agencija, Ministarstvo financija - Carinska uprava, Ministarstvo financija Porezna uprava, Ministarstvo financija - Ured za sprječavanje pranja novca, Ministarstvo financija - Financijski inspektorat Republike Hrvatske, Državno odvjetništvo i sudovi. ${ }^{91}$

Obveze zračnih prijevoznika regulirane su poglavljem II., čl. 10. - 12. Zakona iz 2018. godine. Hrvatski zakonodavac propisao je obvezu zračnog prijevoznika ${ }^{92}$

88 Čl. 6. Zakona iz 2018. godine. Iako je riječ o odredbi koja suštinski odgovara rješenjima čl. 1. i 2. Direktive (EU) 2016/681, hrvatski zakonodavac propisuje područje primjene Zakona iz 2018. godine neovisno o tome je li riječ o letu između EU-a i trećih zemalja (čl. l. st. 1. pod a) Direktive (EU) 2016/681) ili o letu unutar EU-a (čl. 2. Direktive (EU) 2016/681). Naime, prethodno navedenom normom hrvatski zakonodavac jasno propisuje kako se njegova primjena odnosi na sve letove zračnog prijevoznika u hrvatskom zračnom prostoru te letove kojima je polazište u RH (a odredište $u$ drugoj državi) ili je odredište ili međuslijetanje u RH (a polazište je $u$ drugoj državi).

89 Putnik je osoba koja na temelju ugovora sa zračnim prijevoznikom ima pravo na prijevoz zrakoplovom (čl. 3. st. 1. t. 3. Zakona iz 2018. godine). Sadržajno opsežnija definicija putnika sadržana je u čl. 3. st. 1. t. 4. Direktive (EU) 2016/681 - više vidi bilj. 57.

90 Čl. 5. Zakona iz 2018. godine. Riječ je o jedinici za informacije o putnicima unutarnje ustrojstvene jedinice MUP-a koja je ustrojena u Upravi kriminalističke policije, Kriminalističkom obavještajnom sektoru i Službi kriminalističko-obavještajne analitike. PIU trenutačno raspolaže API podacima na dolaznim letovima iz trećih zemalja, a PNR podacima još ne raspolaže (u tijeku su povezivanja s rezervacijskim sustavima zračnih prijevoznika s ciljem preuzimanja podataka i očekuje se prvo preuzimanje putnika od nacionalnog zračnog prijevoznika kroz rezervacijski sustav AMADEUS) - vidi 13. Godišnje izvješće Vlade RH o provedbi Strategije integriranog upravljanja granicom Republike Hrvatske za 2018. godinu, svibanj 2019., str. 54, https:// vlada.gov.hr/UserDocsImages//2016/Sjednice/2019/Lipanj/161\%20sjednica\%20 VRH//161\%20-\%2022.l.pdf (25. kolovoza 2019.). Detaljnije o nadležnosti i postupanju s podacima od strane PIU-a vidi čl. 7. - 9. Zakona iz 2018. godine.

91 Čl. 16. st. 1. Zakona iz 2018. godine.

92 U slučaju zajedničkih letova (code share) jednog zračnog prijevoznika ili više njih podatke jedinici za putnike prenosi zračni prijevoznik koji obavlja let (čl. 10. st. 5. Zakona iz 2018. godine). 
prenijeti ${ }^{33}$ PIU-u podatke o putnicima koje je prikupio u okviru redovitog poslovanja. ${ }^{94}$ Prema odredbi čl. 10. st. 1. Zakona iz 2018. godine možemo zaključiti kako je riječ o prikupljanju i prijenosu 19 kategorija putnikovih podataka koji, u pravilu, odgovaraju rješenjima Priloga I. Direktive (EU) 2016/681..$^{95}$ Budući da je odredbom čl. 8. st. 2. Direktive (EU) 2016/681 jasno propisano kako je u pogledu prijenosa podataka riječ o prijenosu API podataka, API podaci koji se prenose odnose se na API podatke iz PNR-a. Zakonom iz 2018. godine propisana je dužnost zračnog prijevoznika prenijeti "potpune i točne informacije o putnicima koje će prevoziti”" š, što je formulacija koju europski zakonodavac u Direktivi (EU) 2016/681 ne koristi. Naprotiv, glede prikupljanja i prenošenja API podataka iz PNR-a još je Prilogom I. Direktive (EU) 2016/681 navedena dužnost zračnog prijevoznika prikupiti "sve informacije o putnicima koje će prevoziti" 97 te iste te podatke prenijeti ${ }^{98}$, ne ulazeći u njihovu točnost i/ili netočnost. ${ }^{99}$ Nužno je upozoriti kako se u pogledu prikupljanja API podataka o putnicima u Prilogu I.

93 Podaci se prenose elektroničkim putem upotrebljavajući zajedničke protokole i podržane formate za prijenos podataka iz evidencije o putnicima, utvrđene provedbenim propisima koje donosi Europska komisija ili, u slučaju tehničke neispravnosti, nekim drugim odgovarajućim načinom koji jamči odgovarajuću razinu sigurnosti podataka (čl. 10. st. 4. Zakona iz 2018. godine). Tako i čl. 16. st. 1. Direktive (EU) 2016/681.

94 Više o prekršajnim sankcijama za pravne osobe koje u svojstvu zračnog prijevoznika ne dostave podatke ili ne dostave sve podatke o putnicima iz čl. 10. st. 1 . ovog Zakona koje prikuplja u okviru redovitog poslovanja vidi čl. 34. st. 1. t. 1. i st. 2. Zakona iz 2018. godine. Detaljnije o prekršajnoj odgovornosti pravne osobe koja u svojstvu zračnog prijevoznika ne dostavi podatke upotrebljavajući utvrđene zajedničke protokole i podržane formate za prijenos podataka odnosno, u slučaju tehničke neispravnosti, neki drugi odgovarajući način koji jamči odgovarajuću razinu sigurnosti podataka vidi čl. 34. st. 1. t. 2. i st. 2. Zakona iz 2018. godine, a o prekršajnoj odgovornosti pravne osobe koja u svojstvu zračnog prijevoznika ne dostavi navedene podatke u propisanom roku vidi čl. 34. st. 1. t. 3. i st. 2. Zakona iz 2018. godine.

95 Razlike hrvatskih i europskih pravnih normi odnose se na kategoriju 18 Priloga I. Direktive (EU) 2016/681, odnosno čl. 10. st. 1. pod 18. Zakona iz 2018. godine, a odnosi se na razlike u sadržaju API podataka iz PNR-a koje je zračni prijevoznik dužan prenijeti PIU-u.

96 Čl. 10. st. 1. pod 10. Zakona iz 2018. godine. Ista formulacija koristi se i u čl. 24. st. 2. Zakona o nadzoru državne granice.

97 Riječ je o podacima koji su taksativno navedeni pod točkom 18. Priloga I. Direktive (EU) 2016/681.

98 Vidi čl. 8. st. 1. Direktive (EU) 2016/681.

99 Vidi bilješku 61. 
Direktive (EU) 2016/681 navodi kako API podaci uključuju i podatke o zemlji izdavanja i datuma isteka bilo kojeg osobnog dokumenta. ${ }^{100}$ Daljnjom usporedbom možemo uvidjeti kako Zakon iz 2018. godine ne zahtijeva od zračnih prijevoznika prenošenje sljedećih API podataka iz PNR-a (koji su kao takvi navedeni Prilogom I. Direktive (EU) 2016/681): spol putnika, zračni prijevoznik, datum polaska i datum odlaska, zračna luka polaska i zračna luka dolaska. ${ }^{101}$ Budući da je Prilogom I. Direktive (EU) 2016/681 jasno propisano koje API podatke iz PNR-a prikupljaju i prenose zračni prijevoznici, uočavamo kako su Zakonom iz 2018. godine necjelovito prenesena rješenja o sadržaju API podataka iz PNR-a, ograničavajući opseg predmetnih podataka samo u odnosu na one API podatke koje navodi Direktiva 2004/82/EZ. Po uzoru na odredbu čl. 6. st. 1. Direktive (EU) 2016/681, Zakonom iz 2018. godine propisano je kako u slučaju ako zračni prijevoznik prenese PIU podatke koji nisu navedeni u čl. 10. st. 1. Zakona iz 2018. godine $^{102}$ - PIU će ih odmah po primitku trajno izbrisati. Naglašavamo kako hrvatski zakonodavac ne propisuje obvezu prijenosa svih API podatke iz točke 18. Priloga I. Direktive (EU) 2016/681, koje je zračni prijevoznik prikupio (ali ih nije zadržao istim tehničkim sredstvima kao i podatke iz PNR-a), po uzoru na rješenje čl. 8. st. 2. Direktive (EU) 2016/681. Na temelju toga možemo uvidjeti kako predmetna rješenja na nacionalnoj razini omogućuju PIU-u da u slučaju kada su im preneseni podaci - npr. o spolu putnika, o zračnom prijevozniku, o datumu polaska i datumu odlaska, o zračnoj luci polaska i zračnoj luci dolaska - PIU navedene podatke odmah trajno izbriše. Na taj način zapravo se gube značajni podaci čija bi obrada i rezultati obrade mogli doprinijeti sprječavanju i suzbijanju terorizma i drugih oblika organiziranog kriminala.

Vremenski rok u kojem je zračni prijevoznik dužan prenijeti PIU-u podatke o putnicima propisan je čl. 1l. st. 1. Zakona iz 2018. godine i iznosi: a) 24 sata prije zakazanog vremena polaska zrakoplova ${ }^{103}$ te b) odmah po zatvaranju leta odnosno nakon što su se putnici ukrcali u zrakoplov koji se sprema za polazak

100 Riječ je o odredbi koja je daleko šira u odnosu na rješenja hrvatskog Zakona iz 2018. godine kojim se od zračnih prijevoznika zahtijeva prenošenje informacija glede broja i vrste "putne isprave" (ne bilo kojeg drugog osobnog dokumenta iz Priloga I. Direktive (EU) 2016/681 poput npr. osobne iskaznice) ne navodeći ujedno kako su zračni prijevoznici dužni prenijeti i podatke glede zemlje izdavanja i datuma isteka roka važenja te putne isprave.

101 Vidi čl. 10. st. 1. pod 18. Zakona iz 2018. godine.

102 Npr. podaci o datumu polaska putnika, zračnoj luci polaska ili neki drugi podaci.

103 Europski zakonodavac propisao je dužni rok “24 do 48 sati prije zakazanog vremena polaska zrakoplova” (čl. 8. st. 3. Direktive (EU) 2016/681). 
i kada se putnici više ne mogu ukrcati ni iskrcati. ${ }^{104}$ Zanimljivo je uočiti kako je hrvatski zakonodavac odredbom čl. 10. st. 6. Zakona iz 2018. godine propisao da se podaci o putnicima prenose bez naknade. Riječ je o pravnoj normi koja nije sadržana u rješenjima Direktive (EU) 2016/681.

\section{ZAKLJUČAK}

Valorizirajući gospodarsku važnost suvremenog europskog zračnog prijevoza putnika i sve učestalije globalne prijetnje terorističkim i drugim sigurnosnim ugrozama, autorica upućuje na teorijsku elaboraciju mjera osnaživanja i osuvremenjivanja europskih sigurnosnih standarda prijevoza putnika u zračnom prometu. Autorica razmatra svrhu, kriterije i opseg primjene pojedinih europskih pravnih rješenja o obvezi zračnih prijevoznika na prikupljanje i prijenos API podataka o putnicima (sadržanim u Direktivi 2004/82/EZ, koja imaju cilj olakšati obavljanje sigurnosnih i graničnih kontrola putnika te spriječiti nezakonite imigracije), ali i API podataka iz PNR evidencije (sadržanih u Direktivi (EU) 2016/681, koja ima cilj sprječavanje, otkrivanje, provođenje istrage i vođenje kaznenog progona za kaznena djela terorizma i teških kaznenih djela). Na temelju regulatorne aktivnosti europskog zakonodavca možemo uvidjeti kako se API podaci i PNR podaci ne odnose u cijelosti na sadržajno iste podatke o putnicima. API podaci službeni su podaci kojima raspolažu zračni prijevoznici, a odnose se na podatke navedene u putnikovim putnim ispravama te podatke o samom prijevozu. U današnje vrijeme prikupljanje, prijenos i obrada API podataka imaju sve značajniju ulogu zbog stalnog porasta broja putnika $u$ zračnom prometu, naglog porasta međunarodnih putovanja i prekogranične prijetnje terorizma. Elektronički prijenos i obrada API podataka doprinosi lakšem i bržem provođenju sigurnosnih i graničnih provjera omogućujući da se predmetni podaci obrade i izvrše procjene sigurnosnih rizika putnika i prije nego što se putnik pojavi na graničnom prijelazu. PNR evidencije obuhvaćaju API podatke, ali i one podatke koje u pravilu prijavljuju sami putnici prilikom rezervacije karata i postupka prijave za let (npr. adresa, kontaktni podaci i dr.). Možemo zaključiti kako usprkos različitosti predmetnih podataka među zračnim prijevoznicima te manjoj pouzdanosti u točnost samih podataka (u odnosu na API podatke) - njihova obrada predstavlja dodatno sredstvo u suzbijanju prekograničnog kriminaliteta.

104 Ovaj rok primjenjuje se samo u odnosu na podatke koji se razlikuju u odnosu na podatke koje je zračni prijevoznik dostavio u roku pod a) - čl. 11. st. 2. Zakona iz 2018. godine. 
Kroz rad su analizirane europske pravne norme obveze zračnih prijevoznika na prikupljanje i prijenos nadležnim tijelima API podataka (prema rješenjima Direktive 2004/82/EZ/) te API podataka iz PNR-a (prema rješenjima Direktive (EU) 2016/681). Prema Direktivi 2004/82/EZ nadležna tijela kojima se API podaci prenose su službeni granični prijelazi preko kojih putnici u zračnom prijevozu ulaze na državno područje države članice. U slučaju prijenosa API podataka iz PNR-a nadležno tijelo kojem se navedeni podaci prenose je PIU države članice (nacionalni PIU), na čijem se državnom području nalazi polazište ili odredište leta. Značajno je upozoriti kako do prenošenja API podataka, prema rješenjima Direktive 2004/82/EZ, dolazi samo na zahtjev tijela odgovornih za kontrolu osoba na vanjskim granicama. Nasuprot tome, API podaci iz PNR-a sustavno se prenose nacionalnom PIU-u na čijem se državnom području nalazi polazište ili odredište leta, omogućujući PIU-u izravan pristup sadržaju tih podataka i njihovoj obradi. Na taj način doprinosi se otkrivanju i praćenju sumnjivih obrazaca putovanja, čime API-PNR sustav osnažuje svoju ulogu kao bitan europski instrument borbe protiv terorizma i teških kaznenih djela.

Preuzimanje i pravilna primjena acquis comunautaire obveza je svih država članica, a puna provedba schengenske pravne stečevine ujedno je strateški cilj RH. Od RH kao države članice EU-a, zemlje s vanjske strane Schengena, očekuje se pojačani nadzor nad vanjskim granicama EU-a s ciljevima sprječavanja nezakonite imigracije, prekograničnog terorizma i drugih oblika organiziranog kriminala. Analizirajući pojedine europske (hrvatske) pravne norme o obvezi zračnih prijevoznika na prikupljanje i prijenos API podataka (Zakon o nadzoru državne granice iz 2013. godine i Zakon iz 2018. godine), možemo zaključiti kako RH uglavnom slijedi rješenja europske pravne stečevine detaljno propisujući obveze zračnih prijevoznika u pogledu prikupljanja i prijenosa podataka o putnicima, načinima, protokolima i formatima za njihov prijenos i obradu i dr. Bitno je naglasiti kako je Zakonom iz 2018. godine propisana dužnost zračnog prijevoznika prenijeti PIU-ima sve API podatke čiji sadržaj odgovara rješenjima Direktive 2004/82/EZ, koja je implementirana u nacionalno zakonodavstvo stupanjem na snagu Zakona o nadzoru državne granice iz 2013. godine. Ipak, Zakonom iz 2018. godine necjelovito su prenesena rješenja sadržana u točki 18. Priloga I. Direktive (EU) 2016/681, koja uređuju obvezu zračnog prijevoznika na prijenos API podataka iz PNR-a, ali i rješenja o roku unutar kojeg je zračni prijevoznik dužan prenijeti podatke. Budući da je riječ o podacima koji se, među ostalim, odnose na zemlju izdavanja i datuma isteka bilo kojeg osobnog dokumenta, spol putnika, zračnog prijevoznika, datum polaska i datum odlaska, zračne luke polaska i zračne luke dolaska - njihovo bi prikupljanje i prijenos trebalo propisati kao obvezu zračnih prijevoznika i u 
hrvatskom pravnom sustavu. Na temelju navedenog, autorica predlaže de lege ferenda izvršiti izmjene i dopune Zakona iz 2018. godine u skladu s postojećim rješenjima Direktive (EU) 2016/681 kao ključnog instrumenta u borbi protiv terorizma i organiziranog kriminala.

Upozoravajući na povećan broj sigurnosnih ugroza i sve učestalije pojave terorističkih aktivnosti u EU-u u pogledu zračnog prijevoza te analizirajući brojna europska i hrvatska pravna rješenja, naglašava se nužnost stvaranja jedinstvenog (međunarodnog) pravnog okvira prikupljanja i prijenosa API podataka u zračnom prometu. Nužnost jedinstvenog pristupa prikupljanju i prenošenju API podataka iz PNR-a na međunarodnoj razini te njihova unificirana primjena imat će osjetno snažniji, učinkovitiji i sveobuhvatniji učinak u borbi protiv terorizma kao globalnog problema i globalne prijetnje. Uzimajući u obzir kako predmetni mehanizam još nije uspostavljen na međunarodnoj razini, naglašava se kako u cilju stvaranja uniformiranih pravnih rješenja, ujednačenog tumačenja i primjene europske pravne stečevine te smanjenje pravne nesigurnosti, sadržaj prikupljanja i prijenosa API podataka iz PNR-a moramo shvaćati jednoznačno na europskoj i nacionalnoj razini.

\section{LITERATURA}

Abeyratne, R., Convention on International Civil Aviation A Commentary, Springer, 2014.

Ball, R., The Legitimacy of the European Union through Legal Rationality, Routledge, London-New York, 2013.

Bigo, D.; Brouwer, E.; Carrera, S.; Guild, E.; Guittet, E. P.; Jeandesboz, J.; Ragazzi, F.; Scherrer, A., The EU Counter-Terrorism Policy Response to the Attacks in Paris: Towards an EU Security and Liberty Agenda, CEPS, Liberty and Security in Europe, br. 81, 2015., str. 1 - 18.

Boehm, F., Confusing fundamental rights protection in Europe: Loopholes in Europe's fundamental rights protection exemplified on European data protection rules, Faculty of Law, Economics and Finance, 2009., str. 1 - 17, https://ssrn.com/ abstract $=1348472$ (11.prosinca 2018.).

Boehm, F., Tit for tat - Europe's revenge for the Canadian and US-American PNR systems? The envisaged European model of analyzing flight passenger data, ERA Forum, vol. 11., br. 2., 2010., str. $251-261$.

Bolanča, D., Prometno pravo Republike Hrvatske, Pravni fakultet u Splitu, Split, 2016.

Brouwer, E., Ignoring Dissent and Legality The EU's proposal to share the personal information of all passengers, CEPS, Liberty and Security in Europe, 2011., str. $1-17$. 
De Hart, P.; Bellanova, R., Transatlantic Cooperation on Travelers' Data Processing: From Sorting Countries to Sorting Individuals, Migration Policy Institute, 2011., str. $1-27$.

Duchesneau, J.; Langlois, M., Airport attacks: The critical role airports can play in combatting terrorism, Journal of Airport Management, vol. 11, br. 4, 2017., str. $342-354$.

Grabovac, I.; Kaštela, S., Međunarodni i nacionalni izvori hrvatskoga prometnog prava, HAZU- Književni krug, Zagreb-Split, 2013.

Guild, E.; Carrera, S.; Geyer, F., The Commission's New Border Package Does it take us one step closer to a „cyber-fortress Europe“?, CEPS Policy brief, br. 154, 2008. str. $1-5$.

Hlača, V., Hrvatsko prometno pravo $i$ međunarodne konvencije, Pravni fakultet $\mathrm{u}$ Rijeci, Rijeka, 2000.

Horjan, A. M.; Šuperina, M., Izgradnja strategije unutarnje sigurnosti Europske unije: $U$ pet koraka prema sigurnijoj Europi, Policijska sigurnost, vol. 21, br. 1, 2012., str. $70-104$.

Kraus, J.; Verner, T., Using sensor network for passengers prescreening in air transport, Journal of Transportation Security, vol. 9, br. 3-4, 2016., str. 117 - 124.

Lee, A. J.; Nikolaev, A. G.; Jacobson, S. H., Protecting air transportation: a survey of operations research application to aviation security, Journal of Transportation Security, vol. 1, br. 3, 2008., str. 160 - 184.

Leonard, S., The use and effectiveness of migration controls as a counter-terrorism instrument in the European Union, University of Salford, Manchester, 2010., str. 32 -50, http://usir.salford.ac.uk/18771/1/SL_CEJISS_border_controls_CT.pdf (16.studenoga 2018.).

Manteghi, M., Discussing Initiatives for an EU Passenger Name Records System in Light of Already Existing Data Processing Measures in the Field of Border Control, 2017., str. 1 - 9, https://ssrn.com/abstract=3082412 (15.siječnja 2019.).

Martin, G.; Prager, F., Terrorism: An International Perspective, SAGE Publications Ltd, 2019.

Nino, M., The protection of personal data in the fight against terrorism - New perspectives of PNR European Union instruments in the light of the Treaty of Lisbon, Utrecht Law Journal, vol. 6, br. 1, 2010., str. $62-85$.

Rossi Del Pozzo, F., EU Legal Framework for Safeguarding Air Passenger Rights, Springer, 2014.

Rossi Del Pozzo, F., International and EU legal frameworks of aviation security, u: Szyliowicz, J. S.; Zamparini, L. (ur.), Air Transport Security Issues Challenges and National Policies, Edward Elgar Publishing, 2018. 
Savić, I., Zračni promet, u: Radionov, N.; Marin, J. (ur.), Europsko prometno pravo, Pravni fakultet Sveučilišta u Zagrebu, Zagreb, 2011., str. 337 - 463.

Vasile, S. A.; Popescu, O., Smart Borders - Initiatives and Perspectives of the Information Flows Management within Schengen Area, Journal of Criminal Investigation, vol. 5, br. 1, 2012., str. $178-183$.

Weber, L., Aviation Security, u: Giemulla, E.; Weber, L. (ur.), International and EU Aviation Law, Kluwer Law International, 2011., str. 285 - 306.

Weber, L., The Chicago Convention, u: Dempsey, P. S.; Jakhu, R. S. (ur.), Routledge Handbook of Public Aviation Law, Routledge, 2016., str. 9 - 32.

Wilson, K., Gone With the Wind?: The Inherent Conflict between API/PNR and Privacy Rights in an Increasingly Security-Conscious World, Air and Space Law, vol. 41, br. 3, 2016., str. $229-264$.

\section{PROPISI I DRUGI AKTI}

Annex 9 to the Convention on International Civil Aviation, 15. izdanje, https://www. icao.int/WACAF/Documents/Meetings/2018/FAL-IMPLEMENTATION/ an09_cons.pdf (19. ožujka 2019.).

Direktiva 2004/82/EZ o obvezi prijevoznika na dostavljanje podataka o putnicima, Službeni list Europske unije, L 261, 6. kolovoza 2004., str. 24 - 27.

Direktiva (EU) 2016/681 o uporabi podataka iz evidencije podataka o putnicima (PNR) u svrhu sprečavanja, otkrivanja, istrage i kaznenog progona kaznenih djela terorizma i teških kaznenih djela, Službeni list Europske unije, L 119, 4. svibnja 2016., str. 132 - 149.

Direktiva (EU) 2017/541 Europskog parlamenta i Vijeća od 15. ožujka 2017. o suzbijanju terorizma i zamjeni Okvirne odluke Vijeća 2002/475/PUP i o izmjeni Odluke Vijeća 2005/671/PUP, Službeni list Europske unije, L 88, 31. ožujka 2017., str. 6 - 21 .

Konvencija o međunarodnom civilnom zrakoplovstvu iz 1944. god, https:// www.icao.int/secretariat/legal/List\%20of\%20Parties/Chicago_EN.pdf (13. ožujka 2019.)

Konvencija Vijeća Europe o sprječavanju terorizma, Službeni list Europske unije, L 159, 22. lipnja 2018., str. 3 - 14.

Nacionalne mjere za prenošenje koje su države članice dostavile u vezi sa sljedećom direktivom: Direktiva Vijeća 2004/82/EZ od 29. travnja 2004. o obvezi prijevoznika na dostavljanje podataka o putnicima, Službeni list Europske unije, L 261, 6. kolovoza 2004., str. 24 - 27. 
Nacionalne mjere za prenošenje koje su države članice dostavile u vezi sa Direktivom (EU) 2016/681, Službeni list Europske unije, Službeni list Europske unije, L 119, 4. svibnja 2016., str. 132 - 149.

Odluka o donošenju Nacionalnog programa za olakšice, Narodne novine, br. $105 / 2015$.

Odluka o osnivanju Nacionalnog povjerenstva za olakšice, Narodne novine, br. 129/2017.

Okvirna odluka Vijeća od 13. lipnja 2002. o suzbijanju terorizma - 2002/475/ PUP, Službeni list Europske unije, L 164, 22. lipnja 2002., str. 3 - 7.

Provedbena odluka Komisije (EU) 2017/759 od 28. travnja 2017. god. o zajedničkim protokolima i formatima podataka koje zračni prijevoznici trebaju upotrebljavati pri prijenosu podataka iz evidencije podataka o putnicima (PNR) odjelima za informacije o putnicima, Službeni list Europske unije, L 113, 29. travnja 2017., str. $48-51$.

Strategija zrakoplovstva za Europu, $\operatorname{COM(2015)~} 598$ final, 7. prosinca 2015., pod 2.3., https://eur-lex.europa.eu/legal-content/HR/TXT/HTML/?uri=CELEX:52015DC0598\& from=EN (10. siječnja 2019.).

Uredba (EU) 2016/679 Europskog parlamenta i Vijeća od 27. travnja 2016. o zaštiti pojedinaca u vezi s obradom osobnih podataka i o slobodnom kretanju takvih podataka te o stavljanju izvan snage Direktive 95/46/EZ (Opća uredba o zaštiti podataka), Službeni list Europske unije, L 119, 4. svibnja 2016., str. $1-88$.

Vijeće Europe, Strategija Europske unije za borbu protiv terorizma, http://register.consilium.europa.eu/doc/srv?l=EN\&f=ST\%2014469\%202005\%20REV\%204 (12. ožujka 2019.).

Zakon o nadzoru državne granice, Narodne novine, br. 83/2013.

Zakon o dopuni Zakona o nadzoru državne granice, Narodne novine, br. 27/2016.

Zakon o prijenosu i obradi podataka o putnicima u zračnom prometu u svrhu sprječavanja, otkrivanja, istraživanja i vođenja kaznenog postupka za kaznena djela terorizma i druga teška kaznena djela, Narodne novine, br. 46/2018.

Zakon o zračnom prometu, Narodne novine, br. 69/2009, 84/2011, 54/2013, 127/2013, 92/2014. 


\section{OSTALA DOKUMENTACIJA}

Canetta, E.; Korpelainen, S.; Mortera, C.; Robson, L.; Minkova, V.; Damianakis, K., Evaluation on the implementation and functioning of the obligation of carriers to communicate passenger data set up by Directive 2004/82, 17. rujna 2012., https:// ec.europa.eu/home-affairs/sites/homeaffairs/files/elibrary/documents/policies/ irregular-migration-return/return-readmission/docs/evaluation_of_the_api_ directive_en.pdf (11. listopada 2019.).

Eurocontrol, 2018's air traffic in a nutshell, https://www.eurocontrol.int/ news/2018s-air-traffic-nutshell (10. siječnja 2019.).

Europska Komisija: Politike Europske unije: Promet, 2014., https://europa.eu/european-union/topics/transport_hr (11. travnja 2019.).

Europska komisija, Europa bez granica - Schengenski prostor, http://publications. europa.eu/resource/cellar/09fcf4lf-ffc4-472a-a573-b46f0b34119e.0001.01/ DOC_l (16. listopada 2019.).

Godišnje izvješće o radu Nacionalnog povjerenstva za olakšice za 2012.god., 5.ožujka 2013., https://vlada.gov.hr/UserDocsImages//2016/Sjednice/Arhiva//92.\%20 -\%2017c.pdf (11. veljače 2019.).

Report from the Commission on financing aviation security, COM/2009/0030 final, 2. veljače 2009., https://eur-lex.europa.eu/legal-content/HR/TXT/?uri=CELEX:52009DC (10. siječnja 2019.).

Vlada RH, 12. Izvješće o provedbi Strategije integriranog upravljanja granicom Republike Hrvatske za 2017. god., 2018., https://vlada.gov.hr/UserDocsImages//2016/ Sjednice/2018/10\%20listopad/118\%20sjednica\%20VRH/Novo//118\%20-\%20 13.pdf (14. lipnja 2019.)

Vlada RH, 13. Godišnje izvješće o provedbi Strategije integriranog upravljanja granicom Republike Hrvatske za 2018., 2019., https:/vlada.gov.hr/UserDocsImages//2016/ Sjednice/2019/Lipanj/161\%20sjednica\%20VRH//161\%20-\%2022.I.pdf (25. kolovoza 2019.).

Vlada Republike Hrvatske, Izvješće o provedbi Strategije nacionalne sigurnosti Republike Hrvatske, 2019., https://vlada.gov.hr/UserDocsImages//Sjednice/2019/..//138\%20-\%203.pdf (10. listopada 2019.). 
Summary

\section{Željka Primorac*}

\section{CURRENT LEGAL ISSUES ON AIR CARRIERS' OBLIGATION TO COLLECT AND TRANSMIT PASSENGER DATA UNDER THE LATEST EUROPEAN (CROATIAN) REGULATION}

The thematic concept of this paper comprises legal issues regarding the role and importance of air carriers' obligation to collect and transmit passenger data (including data concerning transport itself) that serve to identify passengers with a view to improving the entry controls into the EU. This study also aims at carrying out a legal analysis of certain aspects of air carriers' obligation with regard to the systematic collection and transmission of a high amount of personal information on passengers with a view to preventing, detecting, investigating and prosecuting terrorist offences and serious criminal offences. By analysing the purpose, scope, criteria and issues of applying the existing provisions at the European level (Directive 2004/82/EC and Directive (EU) 2016/681), the author pays special attention to the modalities of transposing European law into the Croatian legal order (State Border Control Act of 2013 and the Act on the Transmission and Processing of Air Passengers' Data for the Prevention, Detection, Investigation and Prosecution of Terrorist Offences and Other Serious Criminal Offences of 2018). By clearly pointing out the significant content differences within the European and national provisions, the author emphasises the importance of the open issue of incomplete regulation of air carriers' obligation to transmit API passenger data from the PNR record in the Croatian legal system. By offering proposals de lege ferenda, the author advocates uniformity in the interpretation, transposition and application of European law.

Keywords: collection and transmission of API passenger data, air carriers' obligation, European (Croatian) law

Željka Primorac, Ph. D., Associate Professor, Faculty of Law, University of Split, Domovinskog rata 8, Split; zeljka.primorac@pravst.hr;

ORCID ID: orcid.org/0000-0002-9880-0369 
